Saudi Journal of Humanities and Social Sciences

Abbreviated Key Title: Saudi J Humanities Soc Sci

ISSN 2415-6256 (Print) | ISSN 2415-6248 (Online)

Scholars Middle East Publishers, Dubai, United Arab Emirates

Journal homepage: https://saudijournals.com/sjhss

Review Article

\title{
Unmasking the Masque of Metaphor in the Alchemist
}

\author{
Komal Yadav*
}

PhD Scholar, Department of English, Chandigarh University, Punjab, India

\author{
DOI: $10.36348 /$ sjhss.2020.v05i04.006
}

| Received: 16.04.2020 | Accepted: 27.04.2020 | Published: 30.04.2020

*Corresponding author: Komal Yadav

Abstract

Jonson's The Alchemist is his magnum opus that aims an alchemical magnum opus of characters to expose the gullibility $\&$ follies of humankind. T.S Eliot commends by saying "The plot does not hold together, what holds the play together is its unity" alluding to Ben's classical standards. The magisterium of Ben Jonson is The Alchemist. Being a filius artis, Ben exhibited his exemplary dramatic skills. Ben Jonson is one of the genuine satirists of English literature who follows the Rabelais and Moliere forms. He is noted for his strident criticism of human nature. This is one such play which follows three classical unities. According to Coleridge, "Upon my world, I think, The Oedipus Tyranus, The Alchemist and Tom Jones are the three most perfect plots ever planned." (Coleridge) Ben Jonson excelled as arcana of professions, carved The Alchemist as a work of imaginative extravagance and moral logic. With his repertoire, Benjamin Jonson emulates a conman with his vast diction filled with the jargons of conmen and the gulls. Jonson tries to satirize the fallibility of his contemporary England. The city of London was the breeding-house of all vices. As a satirist, he obliged to tend those vices and purgate his corrupted city. The present paper tries to unfurl the metaphor in Ben Jonson's play The Alchemist i.e. 'alchemy'. Alchemy is the branch of chemistry which deals with the art of transforming baser metals into gold. It is a medieval fantasy which was to gain the Philosopher's stone which is a Panacea and a key to immortality. Jonson alludes this art to life. Through this play, he himself becomes an Alchemist at the end.

Keywords: Alchemy, Metaphor, Sin, Vices, Transmutation, London.

Copyright @ 2020: This is an open-access article distributed under the terms of the Creative Commons Attribution license which permits unrestricted use, distribution, and reproduction in any medium for non-commercial use (NonCommercial, or CC-BY-NC) provided the original author and source are credited.

\section{UNMASKING THE MASQUE OF METAPHOR IN THE ALCHEMIST}

Benjamin Jonson a commanding literary figure who remained a literary dictator of London for twentyfive years. William J. Long said "his comedies are worthy of careful reading, - they are intensely realistic, presenting -men and women of the time exactly as they were". Jonson's The Alchemist is his magnum opus that aims an alchemical magnum opus of characters to expose the gullibility \& follies of humankind. T.S Eliot commends by saying "The plot does not hold together, what holds the play together is its unity" alluding to Ben's classical standards. The magisterium of Ben Jonson is The Alchemist. Being a filius artis, Ben exhibited his exemplary dramatic skills. Ben Jonson is one of the genuine satirists of English literature who follows the Rabelais and Moliere forms. He is noted for his strident criticism of human nature. This is one such play which follows three classical unities. According to Coleridge,

\begin{abstract}
"Upon my world, I think, The Oedipus Tyranus, The Alchemist and Tom Jones are the three most perfect plots ever planned." (Coleridge)
\end{abstract}

The edifices of Jonsonian plays are exquisite. His works failed to capture the minds of the critics in spite of his uniqueness. Jonson's abilities were overcast by the Shakespearean tide. His creative genius was not passed on to the successive generations. Jonson's The Alchemist is one of the elaborate works on Alchemy. The play is a careful exposition of the medieval novelties which fantasized Europeans during the days of Jonson. The play also deals with the Oriental arts such as Feng shui, Chiromancy, metoposcopy and at instances about adulteration. This drama is still acclaimed to be a piece of Alchemy itself because the ingredients (characters) are of inferior qualities which undergo a dramatic of course traumatic process to get "golden" results. This paper tries to emanate the art of Chrysopoeia and how the author utilizes "Alchemy" in its truest sense. 
To demystify alchemy as a metaphor in the play it's essential to know this art on practical or exoteric level as well as philosophical or esoteric level the latter of which has spiritual and remedial references outside its basic chrysopeia. Exoteric alchemy is limited to transmutation of "prima materia" into gold whereas in esoteric alchemy "the mundane transmutation of metals becomes merely symbolic of the transformation of sinful man into perfect human being" (E.J. Holmyard). Human condition is the prime concern that Jonson has worked upon. In the prologue Jonson clears his intention:

\section{"Through this pen did never aim to grieve, but better men; \\ Howe'er the age he lives in doth endure the vices that she breeds, \\ Above their cure. But when the wholesome remedies are sweet....... \\ No spirit so much diseased, but will with fair correctives be pleased" (lines 11-16)}

Ben Jonson excelled as arcana of professions, carved The Alchemist as a work of imaginative extravagance and moral logic. With his repertoire, Benjamin Jonson emulates a conman with his vast diction filled with the jargons of conmen and the gulls. Jonson tries to satirize the fallibility of his contemporary England. The city of London was the breeding-house of all vices. As a satirist, he obliged to tend those vices and purgate his corrupted city. Alchemy is the branch of chemistry which deals with the art of transforming baser metals into gold. It is a medieval fantasy which was to gain the Philosopher's stone which is a Panacea and a key to immortality. Jonson eludes this art to life. Through this play, he himself becomes an Alchemist at the end.

The commencement of the play explains the baseness of the characters by their exchange of flawless, filthy abuses. Their charlatanry and hypocrisy unfold in the successive scenes. Alchemy is the art of conversion and transformation; likewise, the ethical deformity of the characters is husked with the tools of satire and comedy. The plot does not move around the characters but the characters themselves run around the plot to contribute their lot. The characters are likened to the baser metals which undergo certain process to get the transformation into gold. Thus the plot itself is a metaphor of Alchemy. Here the characters are stripped off their hypocritical masks. The lapis philosophicus (philosopher's stone) proves to be the de facto which purgates the negative ideals of the so-called gentry. The characters are the personification of the baser instincts and they are metaphorized to be the baser metals. The play's catalyst is the arrival of Lovewit. They undergo a gradual process of transformation and are rightlyrewarded at the end.
The play tries to dig out the underlying, inherent feelings of human conscience. The characters of this play are modeled upon the seven sins.

\begin{tabular}{|l|l|l|}
\hline S. No. & Character & Sin \\
\hline 1. & Mammon & Covetousness (Avaritia) \\
\hline 2. & Dol & Lechery (Luxuria) \\
\hline 3. & Dapper & Sloth (Acedia) \\
\hline 4. & Subtle & Pride (Superbia) \\
\hline 5. & Surly & Wrath (Ira) \\
\hline 6. & Tribulation & Envy (Tristitia) \\
\hline 7. & Face & Gluttony (Gula) \\
\hline
\end{tabular}

Dol is likened to lechery because she is overtly a prostitute. Dapper is the close associate of Sloth because he wanted to make money without much pain. $\mathrm{He}$ is an ultimate believer of fate and luck. He wanted a fortune fairy! As an icon of charlatanry, Subtle is known for his pride. As pride goes before a fall, he falls at the end in the trap of Face and Lovewit. The very name Surly means bad temper. He was carried away by his wrath and lost the argument in the hands of the conmen. This proves the importance of patience. Though Tribulation serves his brethren, he chooses an immoral path to let the Roman Catholics down by bribing the magistrate. Thus, he is likened to the sin of Jealousy. The ubiquitous character of this play, Face changes faces because of his excessive greed. Though he was trusted by his master, he failed to discharge his duty because of his lust for money. This turns him to be a glutton. The characters such as Mammon and Surly bore the semantic reflections of their respective names. Sir Epicure Mammon aspires to gain the control over the natural events as a Spectatissimi and even free the earth from mortality. The Mammon is an epicurean who wants ethereal powers especially his "Fifty a night" whim poses him to be a possible threat of a vaulting ambition. His covetousness is expressed in the following lines:

\section{“The goldenmines Great Solomon's Ophir! he was sailing to it three years, but we've reached in three months" (Act II Scene 1)}

The lust for power of Mammon to surpass nature is expressed in the following lines:

\section{"The secret of nature naturalized against all infections, \\ Curses all diseases coming all causes" (Act II Scene 2)}

The dramatist metaphorizes Lovewit's house to human mind which is engaged by the seven sins, is brought back to normalcy by the arrival of "Lovewit" vis-à-vis 'Love' and 'wit'. The moral turpitude act as the impediments in the spiritual gradation of man. The art of alchemy is the noble art which removes the baseness of a metal and converts those metals to gold. 
This is metaphorized to the scandalous nature of the hypocrites in the society. The lust for alchemy is intensified by the seductive speech of the "noble" duo. The pretense of success in attaining the ruby stone evident in the following line:

\section{"The evening will set red upon you, Sir" (Act II Scene 2)}

The red sky at night is an omen of prosperity. The dramatist utilizes the astronomical allusion (a myth) in the play. The Alchemist also uses the myths such as palmistry, face-reading in order to build the alchemical decorum.

The art of Alchemy demands a pure heart and homo frugi i.e. temperate habits. When man fails to be frugi, his works end in fumo (in fumes). This was the Alchemical message not only for Mammon. Ananias' message to Tribulation is "The sanctified cause should have a sanctified course".

The tripartite of cozeners disguising their authenticity by assuming the role higher to their social position to gull their clients. The ascend or transmutation from housekeeper (Jeremy) to captain face, a prostitute (Dol) to an aristocratic lady or 'queens of faery' \& a conman (Subtle) to an alchemist is analogical to transmutation of base metals into gold . The grandeur with which they use purple phrase to address their fellow conman as if they had setup a commonwealth, where a whore becomes 'Queen Dol', Subtle \& Face are addressed as 'your worship'. The play itself is an alchemy where at superficial level it limits to alchemical jargons \& chemical reactions but deep-seated it is esoteric alchemy with spiritual aims of purification and perfection of nature. The gulls (Dapper, Drugger, Mammon, etc.) on which alchemy has been practiced on thematic level are all exposed of their rapaciousness, follies \& profligacy to the reader. Both gullers as well as gulls aspire to transcend their social positions and attain exalted status the former by cozening their customers and later by possessing philosopher's stone, elixir or familiar spirit. The play is about charlatans who aims to transmute themselves and others into what they are not \& the gulls who are not ready to accept the world at its normalcy thus looking to transcend the status quo by achieving their dreams with help of philosopher's stone. Epicure mammon as the name suggests one Fond of sensual pleasures \& material wealth, his quest for philosopher's stone symbolizes his dream Vision for bounteous power \& wealth which if attained will practice more transmutations by making Dol an empress \& Kastril into witty gallant.

In Act IV Scene 6, Mammon's dreams end up as a failure when face utter "O sir, we are defeated! All the works are flown in Fumo, every glass is burst" (line 57-58), the idea of sensual pleasures is mocked here asserting the idea of purity for successful alchemy. Mammon's quest for power symbolizes contemporary renaissance men with high aspirations seeking their own world. Face (Jeremy, captain face, lungs, etc.) as the name suggests has many faces or as subtle says "all that the Taylor has made" suggesting the attire he carries decides who he is. In my opinion he is true alchemist who may not have alchemical knowledge like subtle but his Witty ideas works no less than an elixir the gulls are seeking for, as he himself boasts " my intelligence costs me more money, then my share often comes too" (Act I Scene 3, 107-108).

The 'venture tripartite' (symbolizing mercury, sulphur \& salt - three essentials of alchemy) confirms alchemy- turning the base (unfulfilled) dreams of their clients about transcending the social position into golden plans that supports their duped Vision. It is the self-delusion of gulls that leads them to become vulnerable victims. Surly as his name suggests arrogant makes several attempts to confront his companion (Mammon) who is ignorant of the hoax occult practices of Subtle, Surly is another alchemist seeking his companion's transmutation. He disguises himself as a Spanish don to collect evidence $\&$ expose the cheaters to mammon but his ingenuity \& hope for transmutation meets failure. Surly's hope of unmasking reality ends up in his own mockery by face whose wit is an invincible tool of the whole alchemical business. The return of Lovewit has been criticized by many as a deliberate ending or artificial resolving of plot and thus his entry is a 'deus ex machina'. Edward partridge said "the non-judgmental ending of the action allows all to endure the most comic of all punishments; they remain themselves a deadly retribution if one is a fool". Face's power of wit works upon his master too who ends up saying "I will be ruled by thee in anything Jeremy" (Act V Scene 5, 143). Major shortcomings of the victims are their capitulation to this occult fraud in hope of achieving exalted status, in the end they remain who they were before like their dupes. After the failure of projecting philosopher's stone when everything ends up in Fumo, the transmutation fails too leaving the base metals as base metals only. So, alchemy in The Alchemist as a metaphor that aims transmutation of characters into better remains unsuccessful alike the chemical process that turned into Fumo.

\section{REFFERENCE}

1. Jonson, B., \& Harp, R. (2001). Ben Jonson's plays and masques: Authoritative texts of Volpone, Epicoene, The alchemist, the masque of blackness, Mercury vindicated from the alchemists at court, Pleasure reconciled to virtue: contexts, backgrounds and sources, criticism. New York: W.W. Norton.

2. Jonson, B., Procter, J., \& Butler, M. (1989). The Selected Plays of Ben Jonson. 1st ed. Cambridge: Cambridge University Press. 
3. Van Dyke, J. (1979). The Game of Wits in the Alchemist. Studies in English Literature, 15001900, 19(2), 253-269

4. ARNOLD, J. U. D. D. (1969). Lovewit's Triumph and Jonsonian Morality: A Reading of "The Alchemist". Criticism, 11(2), 151-166. Retrieved from www.jstor.org/stable/23098527
5. Eliot, T. S. (1934). Elizabethan essays. London: Faber \& Faber.

6. Rebhorn, W. A. (1980). Jonson's "Jovy Boy": Lovewit and the Dupes in "The Alchemist". The Journal of English and Germanic Philology, 79(3), 355-375. Retrieved from www.jstor.org/stable/27708683. 